\title{
Selective Agent and A. tumefaciens Overgrowth-control Antibiotics in Eucalyptus camaldulensis Cotiledonary Culture
}

\author{
Regina Quisen ${ }^{1 *}$, Yohana de Oliveira ${ }^{2}$, Marcos Pileggi ${ }^{3}$, Francine Cuquel$^{2}$ and Marguerite \\ Quoirin $^{2}$ \\ ${ }^{I}$ Embrapa Amazônia Ocidental; Manaus - AM - Brasil. ${ }^{2}$ Universidade Federal do Paraná;Curitiba - PR - Brasil. \\ ${ }^{3}$ Universidade Estadual de Ponta Grossa; Ponta Grossa - PR - Brasil
}

\begin{abstract}
The objectives of the present work were to establish the minimal lethal dose of the selective agent to determine the type and concentration of appropriate antibiotics for the elimination of Agrobacterium tumefaciens inoculated explants, without interfering with the regenerative potential of the E. camaldulensis cotyledonary explants. Nontransformed explants were cultivated in medium supplemented with kanamycin. The results showed that the antibiotic was suitable for the selection of transformed cells in the concentration of $9 \mathrm{mg} \mathrm{L}^{-1}$ as it inhibited the growth of non-transformed cells. Cotyledons infected with A. tumefaciens were cultivated in MS N/2 medium supplemented with BAP, ANA, Km and cefotaxime or Augmentin ${ }^{\circledR}$. The highest average of regenerated shoots by explant $(5,4)$ was observed in the presence of $300 \mathrm{mg} \mathrm{L}^{-1}$ of Augmentin ${ }^{\otimes} / 15$ days, followed by $150 \mathrm{mg} \mathrm{L}^{-1} / 15$ days and $100 \mathrm{mg} \mathrm{L}^{-1} / 30$ days.
\end{abstract}

Key words: Morphogenesis, kanamycin, cefotaxime, augmentin, Agrobacterium tumefaciens, eucalypt

\section{INTRODUCTION}

The antibiotics regularly used in the genetic transformation of plants can perform two functions. The first one concerns the method of selecting the transformed tissues. The second function concerns the suppression or elimination of Agrobacterium tumefaciens from in vitro culture after the co-culture period necessary to transfer T-DNA to the host tissue.

According to Brasileiro and Lacorte (1998), the beginning of the genetic transformation with a disarmed strain of A. tumefaciens is based on the selection of one or more transformed cells which are used to regenerate the transgenic plants. For this, the genetic sequence inserted in the genome plant should contain a selection gene to avoid the regeneration of the untransformed cells. Among these selection genes, the neomycin phosphotransferase gene (nptII) is the most widely used as a selection marker, being responsible for the production of neomycin phosphotransferase II or NPTII enzyme (EC 2.7.1.95) which inactivates different antibiotics of the amino-glycosylated group, such as kanamycins A, B and C, geneticin, neomycin, among others. In the plant cells these

\footnotetext{
*Author for correspondence: regina.quisen@ cpaa.embrapa.br
} 
antibiotics, when applied in appropriate concentrations, act in the synthesis of proteins in mitochondria and chloroplast, reducing the chlorophyll synthesis and inhibiting the growth of untransformed cells (Brasileiro and Aragon, 2001). In this way, the transgenic plants which synthesize the enzyme NPTII can tolerate concentrations of amino-glycosylated antibiotics that are lethal in untransformed plants (Brasileiro and Lacorte, 1998, Benveniste and Davies, 1973). Examples of the use of the kanamycin $(\mathrm{Km})$ in the selection of transgenic plants in tree species are found in the case of Liquidambar styraciflua (Sullivan and Lagrimini, 1993), Populus tremuloides Michx. (Tsai et al., 1994) and Prunus dulcis Mill (Archilletti et al., 1995).

According to Potrykus and Spangenber (1995), the main factors that should be considered when choosing a selective marker gene are: a) its expression should not interfere with the normal metabolism of transformed cells; b) its product should effectively protect the transformed cells from the inhibiting properties of the selective agent growth as well as being well distributed in the tissues, in such a way that it allows a phenotypic clear distinction between the transformed and untransformed cells; c) the exposure of the transgenic explant to the selective agent should not affect its subsequent growth and regeneration in whole and fertile plants.

Concentration of the selective agent, however, can severely affect the untransformed and the transformed cells, as well as making escapes possible (Brasileiro and Lacorte, 1998). According to Gonzáles (2002), in Eucalyptus, the existence of genetic variability for tolerance/resistance to certain antibiotics makes the occurrence of escapes possible, as well as different morphogenic responses to the antibiotics incorporated into the culture medium that may interfere with the in vitro organogenesis of the species.

After the contact period between the cell and the bacterial suspension, the cells of A. tumefaciens are undesirable in the culture and should be eliminated by adding an antibiotic (with good antimicrobial capacity in low concentration, as well as good selective toxicity) to the regeneration medium. The antibiotics most frequently used are cefotaxime, carbenicillin, vancomycin, Augmentin ${ }^{\circledR}$, tetracyclin, rifampicin, ampicillin, moxalactam and timentin, with concentrations that vary from 200 to $1000 \mathrm{mg} \mathrm{L}^{-1}$ (Pollock et al., 1983; Shackelford and Chlan, 1996). They act by inhibiting the last synthesis stage of the bacterial cellular wall. The wide range between the concentrations of antibiotics used by several authors demonstrates the different effects of these compounds in plant tissue cultures, where they can have a phytotoxic and harmful effect, reducing the transformation efficiency of several species or even favouring the regeneration of transformed plants, therefore affecting the growth of plant cells and the organogenesis and somatic embryogenesis processes (Mayolo et al., 2003; Nauerby et al., 1997).

This study had two objectives: first, to establish the lowest lethal dose of the selective antibiotic (kanamicyn), and secondly, to determine the type and the concentration of antibiotics for the elimination of $A$. tumefaciens from inoculated explants of Eucalyptus camaldulensis, without interfering with the regenerative potential of cotyledonary explants.

\section{MATERIALS AND METHODS}

\section{Plant material and in vitro culture:}

Seeds were disinfected through successive washes in ethanol $70 \%(\mathrm{v} / \mathrm{v})$ and Tween $20^{\circledR}(4$ drops $/ 100$ $\mathrm{mL}$ ) for two min, followed by sodium hypochlorite ( $8 \%$ of active chlorine) for $30 \mathrm{~min}$ under agitation and then three successive washes in deionized sterile water. The seeds were inoculated in Petri dishes containing $25 \mathrm{~mL}$ of MS culture medium (Murashige and Skoog, 1962) with half the original concentration of salts (MS/2), $2 \%$ sucrose, $0.6 \%$ agar $\left(\right.$ Vetec $\left.^{\circledR}\right)$, with $\mathrm{pH}$ adjusted to 5.8 and sterilized in an autoclave at 1 atm and $121^{\circ} \mathrm{C}$ for $20 \mathrm{~min}$. The culture was maintained in a growth room in the absence of light for seven days, followed by five days in light conditions.

Both the experiments were carried out in a growth room equipped with fluorescent lamps, supplying a photon flow density of $30 \mu \mathrm{Mol} \mathrm{m} \mathrm{s}^{-1}$, a $16 \mathrm{~h}$ photoperiod at $25 \pm 2^{\circ} \mathrm{C}$.

Cotyledonary explants were isolated from 12 to 15-day-old seedlings, cut at the base of the petiole and transferred with the adaxial face in contact with the culture medium. The callogenesis induction and regeneration medium (MCAC) consisted of MS N/2 medium (MS medium with half total nitrogen) supplemented with $4.4 \mu \mathrm{M}$ BAP, $2.7 \mu \mathrm{M}$ ANA, $2 \%$ sucrose, $0.6 \%$ agar $\left(\right.$ Vetec $\left.^{\circledR}\right)$ and $10 \%$ coconut water $\left(\right.$ Kero-Coco $\left.{ }^{\circledR}\right)$. 
The $\mathrm{pH}$ was adjusted to 5.8 before adding agar and then the medium was autoclaved at $120^{\circ} \mathrm{C}$ and 1.5 atm for $20 \mathrm{~min}$.

\section{Influence of the selective agent on callogenesis} and organogenesis of cotyledonary explants

In this experiment, the level of tolerance of $E$. camaldulensis explants to the antibiotic kanamicin $(\mathrm{Km})$ was evaluated aiming at using it as a selective agent in genetic transformation experiments.

Cotyledonary explants were first cultivated in a MCAC medium supplemented with 0, 10, 20, 40, 60 and $80 \mathrm{mg} \mathrm{L}^{-1}$ of $\mathrm{Km}$, maintained in the dark during the first 30 days and transferred to light until the 60th day. Then, a second experiment was carried out with concentrations of $\mathrm{Km}$ of $0,3,6,9$ and $12 \mathrm{mg} \mathrm{L}^{-1}$ and maintaining the conditions specified in the first experiment. The experiment was repeated twice and conducted with 10 repetitions in the first one and 4 in the second, the Petri dish being considered as an experimental unit and containing 6 and 5 explants each, respectively. After 60 days, the percentage of explants forming calli, calli with buds, oxidized or necrotic explants and the number of buds per callus were evaluated. The transformation $(x+0.5)^{-1}$ was applied to the data expressed in porcent and were submitted to variance analysis (ANOVA) and the means compared by Duncan test at the level of $5 \%$ of significance. Bartlett's test for homogeneity of variances was run before ANOVA.

\section{Efficiency of two antibiotics in Agrobacterium tumefaciens elimination}

For the E. camaldulensis co-cultivation, the disarmed A. tumefaciens $\mathrm{C} 58 \mathrm{C} 1$ strain was used. It contained the binary vector pBIN19 carrying the PcgMT1-GUS-NOS construction, with the reporter gene uidA under control of the promoter of the gene cgMT1 (Laplaze et al., 2002), the selection gene $n p t I I$ for neomycin transferase, under control of the NOS promoter of the gene nopaline synthase. The C58C1 strain was inoculated into liquid YEB medium supplemented with $\mathrm{Km}$ (50 $\mathrm{mg} \mathrm{L}^{-1}$ ) and grown $16 \mathrm{~h}$ at $28^{\circ} \mathrm{C}$, with shaking at $120 \mathrm{rpm}$. Cultures were centrifuged at $5000 \mathrm{rpm}$ for $10 \mathrm{~min}$. followed by resuspension in MS/2 medium until reaching a $\mathrm{DO}_{600 \mathrm{~nm}}$ of 0.5 .

The excised cotyledonary explants were transferred into tubes containing the Agrobacterium suspension and shaken for $30 \mathrm{~min}$. at $120 \mathrm{rpm}$. After the infection period, the explants were blotted dry on sterile filter paper in order to remove the excess liquid medium, placed in Petri dishes containing MCAC medium and sealed with plastic film, in which they stayed in co-cultivation in the dark at $25 \pm 2^{\circ} \mathrm{C}$ for 72 hours.

After the period of co-cultivation, the cotyledons were cultivated with the adaxial face in contact with the media containing the antibiotics specified in Figure 1 and $\mathrm{Km}\left(9 \mathrm{mg} \mathrm{L}^{-1}\right)$. They were then kept in the dark for 30 days. After four weeks, the cultures were transferred to new medium corresponding to each treatment and maintained in a growing room until the $60^{\text {th }}$ day. The treatments were based in most frequentky concentration used by the Eucalyptus genus.

Control consisted of non-inoculated explants cultivated in an antibiotic-free MCAC medium (selective and bactericidal). The experiment was conducted with four repetitions (Petri dishes) per treatment with 10 explants in each Petri dish.

After 60 days, the following factors were evaluated: percentage of explants forming calli without buds, percentage of callus regenerating buds, number of buds per callus and percentage of oxidized and contaminated explants were visually detected due to the reappearance of $A$. tumefaciens in the culture. The transformation $(x+0,5)^{-1}$ was applied to the data expressed in porcent and submitted to variance analysis (ANOVA) and the means were compared by Duncan test at the level of $5 \%$ of significance. Bartlett's test for homogeneity of variances was run before ANOVA. 


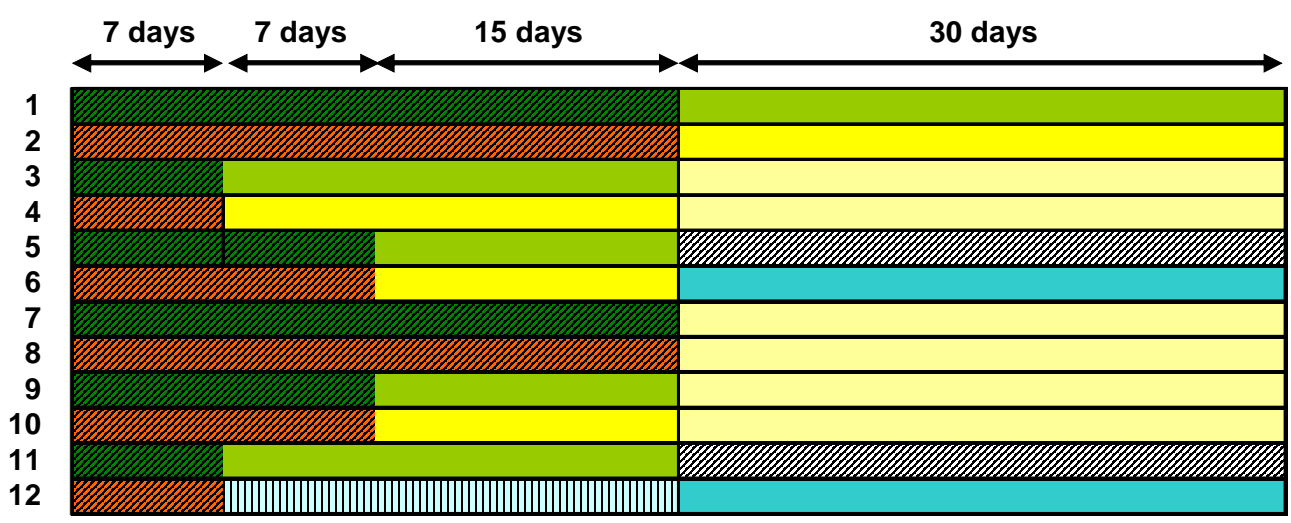

Figure 1 - Periods of exposure of Eucalyptus camaldulensis cotyledonary explants inoculated with A. tumefaciens to different cefotaxime ( $\mathrm{Cx}$ ) and Augmentin ${ }^{\circledR}$ (Aug) concentrations

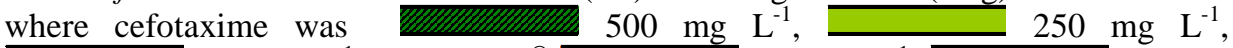

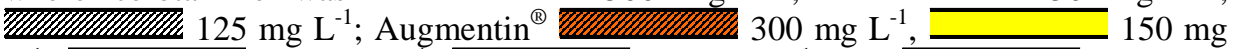

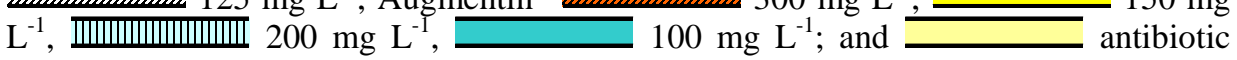
free.

\section{RESULTS AND DISCUSSION}

\section{Susceptibility of $\boldsymbol{E}$. camaldulensis to kanamycin}

All the treatments used in the preliminary experiment were highly toxic to cotyledonary explants, except the concentration of $10 \mathrm{mg} \mathrm{L}^{-1}$ $\mathrm{Km}$ which allowed the formation of calli in $56.7 \%$ of the explants, which was not observed in the other treatments. This result indicated the necessity to repeat the experiment with lower concentrations of kanamycin.

The results of Table 1 showed that the callogenic and organogenic capacity of E. camaldulensis cotyledonary explants was strongly influenced by the selective agent added to the medium, starting with 1.5 buds/callus for $3.0 \mathrm{mg} \mathrm{L}^{-1} \mathrm{Km}$, which represented a reduction of $50 \%$ in the averages obtained with the control treatment (Table 1).

With the gradual increase of $\mathrm{Km}$ in the culture medium, the cellular division was reduced inhibiting organogenesis and giving the explants a chlorotic or necrotic appearance at the end of 60 days of culture (Fig. 2 A-F). This elevated toxicity of $\mathrm{Km}$ in Eucalyptus tissues has been observed by several authors, such as González (2002) in E. grandis. Within the Eucalyptus genus several responses to the different amino-glycosylated antibiotics are found, characterized as speciesdependent. For instance in cotyledons and hypocotyls of E. globulus (Moralejo et al., 1998) and E. grandis $x$ E. urophylla (Cheng et al., 1996), the lowest lethal concentration of $\mathrm{Km}$ was $75 \mathrm{mg}$ $\mathrm{L}^{-1}$ and $40 \mathrm{mg} \mathrm{L}^{-1}$, respectively.

In E. camaldulensis, Ho et al. (1998) observed a reduction in the formation of calli and buds in hypocotyls cultivated in the presence of $20 \mathrm{mg} \mathrm{L}^{-1}$ $\mathrm{Km}$ and regeneration was completely inhibited with $40 \mathrm{mg} \mathrm{L}^{-1}$. However, Mullins et al. (1997) concluded that $9.0 \mathrm{mg} \mathrm{L}^{-1} \mathrm{Km}$ was enough to inhibit the regeneration of buds in some clones of this species, the same lethal minimum concentration found in the present study for bud regeneration.

Yepes and Aldwinckle (1994) considered Km as an inhibiting agent for an apple tree regeneration process that could be used in low concentrations. Cervera et al. (1998), however, emphasized that the smaller the antibiotic selection pressure, the greater the probability of the emergence of escape plants probably due to the protection of untransformed cells by neighbouring transformed cells.

It was also observed that the higher concentrations of the selection agent provoked a larger loss of explants due to tissue oxidation or necrosis (Fig. 2). According to Picoli et al. (2002), necrosis occurrence, phenolic exudation and explant oxidation was problems that required more research in Eucalyptus species regeneration protocols. 

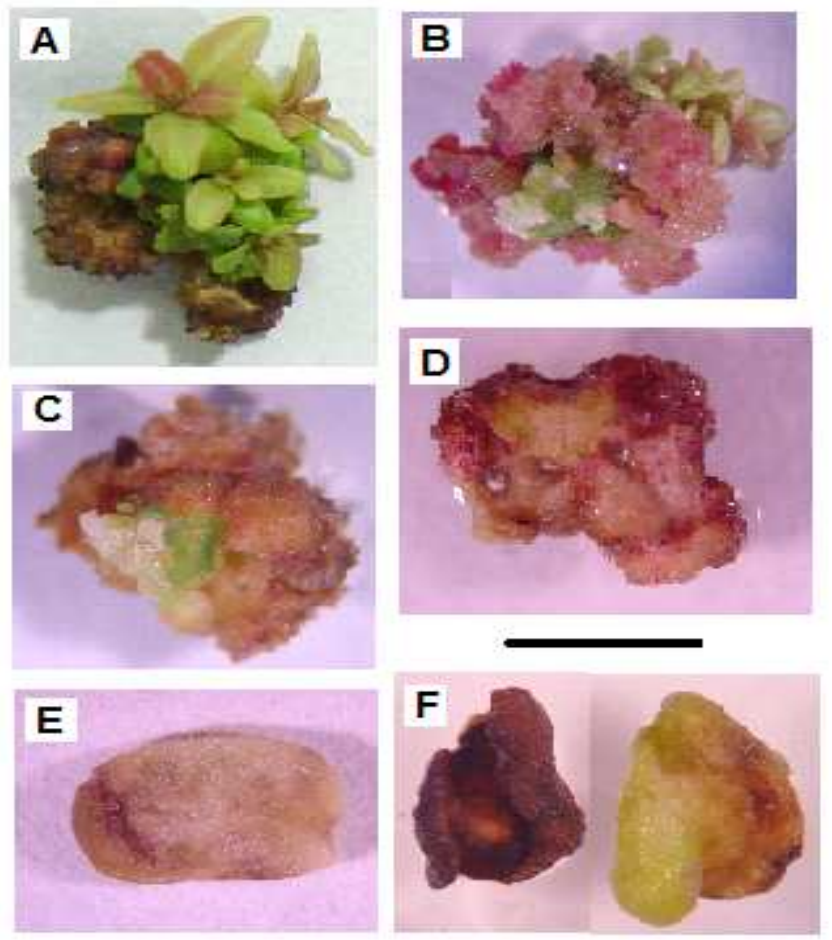

Figure 2 - Effect of kanamycin $(\mathrm{Km})$ concentrations on E. camaldulensis cotyledonary explants after 60 days of in vitro culture. A - control (antibiotic-free medium); B - $3 \mathrm{mg} \mathrm{L}^{-1}$ $\mathrm{Km}$; C - $6 \mathrm{mg} \mathrm{L}{ }^{-1} \mathrm{Km}$; D - $9 \mathrm{mg} \mathrm{L}^{-1} \mathrm{Km}$; E and F - $12 \mathrm{mg} \mathrm{L}^{-1} \mathrm{Km}$. Bar $=1 \mathrm{~cm}$.

Evaluation of the effect of antibiotics on organogenesis in cotyledonary explants

All the evaluated factors in the E. camaldulensis cotyledonary explants cultured in MCAC culture medium in the presence of antibiotics presented significant statistical differences (Table 2). The occurrence of contamination due to the Agrobacterium reappearance was observed in treatments $3,4,7,8,9,10$ and 11 , with losses varying between 2.5 and $97.5 \%$. Except for treatment 11, all these media were free of antibiotics after 30 days (Fig. 1). In these cases, the concentration and duration of application of the antibiotic in the culture medium were not enough to eliminate Agrobacterium. Although treatment 11 contained cefotaxime until the $60^{\text {th }}$ day of culture with an initial concentration of 500 $\mathrm{mg} \mathrm{\textrm {L } ^ { - 1 }}$ for seven days, it was insufficient to completely disinfect the plant material.

These results indicated the need to maintain the bactericidal agent during the whole phase of transformed plant production. Mayolo et al. (2003) also indicated that Agrobacterium was not eliminated during the genetic transformation of Theobroma cacao in culture medium supplemented with cefotaxime at 100 and $300 \mathrm{mg}$ $\mathrm{L}^{-1}$ for 10 weeks after cocultivation, being responsible for the contamination of $8 \%$ and $15 \%$ of the explants, respectively.

The occurrence of oxidation in treatments 1 and 2, 8,10 and 11 suggested that high antibiotic concentrations was toxic for the E. camaldulensis explants, mainly in the initial steps of cellular differentiation and regeneration. In other works with E. camaldulensis leaf explants (Mullins et al., 1997) or hypocotyl and cotyledon explants (Harcourt et al., 2000), it was concluded that 200 $\mathrm{mg} \mathrm{L}^{-1}$ of cefotaxime did not affect the morphogenic capacity of the explants. On the other hand, Kawasu et al. (1996), working with nodal segments of the same species, defined this concentration between 300 and $500 \mathrm{mg} \mathrm{L}^{-1}$.

With regard to the average number of buds per callus, the reduction of Augmentin ${ }^{\circledR}$ concentration from $300 \mathrm{mg} \mathrm{L}^{-1}$ to half strength (for 15 days), followed by $100 \mathrm{mg} \mathrm{L}^{-1}$ (for 30 days) in treatment 6 allowed bud formation with a mean number per explant similar to the number obtained with the control treatment (5.4 buds per callus) (Table 2). 
Table 1 - Effect of $\mathrm{Km}$ in concentrations $\leq 12 \mathrm{mg} \mathrm{L}^{-1}$ on the callogenesis and organogenesis of E. camaldulensis cotyledons after 60 days of cultivation.

\begin{tabular}{ccccc}
\hline $\begin{array}{c}\text { Km concentration } \\
\left(\mathbf{m g ~ L}^{-1}\right)\end{array}$ & $\begin{array}{c}\text { \% of explants } \\
\text { with callus }\end{array}$ & $\begin{array}{c}\text { \% of callus } \\
\text { with buds }\end{array}$ & $\begin{array}{c}\text { Mean number of } \\
\text { shoot per callus }\end{array}$ & $\begin{array}{c}\text { \% of oxidized or } \\
\text { necrotic explants }\end{array}$ \\
\hline 0 & $37.5 \mathrm{ab}$ & $60.0 \mathrm{a}$ & $3.2 \mathrm{a}$ & $2.5 \mathrm{c}$ \\
3.0 & $52.5 \mathrm{a}$ & $32.5 \mathrm{a}$ & $1.5 \mathrm{~b}$ & $15.0 \mathrm{c}$ \\
6.0 & $30.0 \mathrm{~b}$ & $10.0 \mathrm{~b}$ & $0.2 \mathrm{c}$ & $60.0 \mathrm{~b}$ \\
9.0 & $32.5 \mathrm{ab}$ & $0.0 \mathrm{~b}$ & $0.0 \mathrm{c}$ & $67.5 \mathrm{~b}$ \\
12.0 & $5.0 \mathrm{c}$ & $0.0 \mathrm{~b}$ & $0.0 \mathrm{c}$ & $95.0 \mathrm{a}$ \\
\hline
\end{tabular}

Mean of two experiments. Means followed by the same letter in a column are not significantly different at $\mathrm{P} \geq 0.05$ (Duncan test).

Table 2 - Effect of cefotaxime and Augmentin ${ }^{\circledR}$ in the callogenesis and organogenesis of E. camaldulensis cotyledonary explants after 60 days in vitro culture.

\begin{tabular}{|c|c|c|c|c|c|c|c|c|c|c|}
\hline \multirow{2}{*}{$\begin{array}{c}\text { Treatment } \\
1\end{array}$} & \multicolumn{2}{|c|}{$\begin{array}{l}\% \text { of explants } \\
\text { with callus } \\
\text { callus }\end{array}$} & \multicolumn{2}{|c|}{$\begin{array}{c}\text { \% of callus with } \\
\text { buds }\end{array}$} & \multicolumn{2}{|c|}{$\begin{array}{l}\text { Mean number } \\
\text { of shoot per } \\
\text { callus }\end{array}$} & \multicolumn{2}{|c|}{$\begin{array}{l}\% \text { of oxidized } \\
\text { explants }\end{array}$} & \multicolumn{2}{|c|}{$\begin{array}{c}\% \text { of } \\
\text { contaminated } \\
\text { explants }\end{array}$} \\
\hline & 55.0 & $a b c$ & 35.0 & $a b c$ & 1.3 & $\mathrm{~d}$ & 10.0 & $a b$ & 0.0 & $\mathrm{~d}$ \\
\hline 2 & 52.5 & $a b c$ & 45.0 & $\mathrm{ab}$ & 4.2 & b & 2.5 & $\mathrm{~cd}$ & 0.0 & d \\
\hline 3 & 0.0 & $\mathrm{e}$ & 5.0 & ef & 0.7 & $\mathrm{e}$ & 0.0 & d & 95.0 & $\mathrm{a}$ \\
\hline 4 & 17.5 & $\mathrm{de}$ & 25.0 & bcde & 1.4 & $\mathrm{~d}$ & 0.0 & d & 57.5 & b \\
\hline 5 & 72.5 & b & 27.5 & bcd & 2.5 & c & 0.0 & $\mathrm{~d}$ & 0.0 & d \\
\hline 6 & 45.0 & bcd & 55.0 & $\mathrm{ab}$ & 5.4 & $\mathrm{a}$ & 0.0 & d & 0.0 & $\mathrm{~d}$ \\
\hline 7 & 2.5 & $\mathrm{e}$ & 0.0 & $\mathrm{f}$ & 0.0 & $\mathrm{f}$ & 0.0 & d & 97.5 & $\mathrm{a}$ \\
\hline 8 & 35.0 & $\mathrm{~cd}$ & 7.5 & def & 0.1 & $\mathrm{f}$ & 2.5 & $\mathrm{~cd}$ & 55.0 & b \\
\hline 9 & 5.0 & $\mathrm{e}$ & 0.0 & $\mathrm{f}$ & 0.0 & $\mathrm{f}$ & 0.0 & d & 95.0 & $\mathrm{a}$ \\
\hline 10 & 55.0 & $a b c$ & 7.5 & def & 0.1 & $\mathrm{f}$ & 5.0 & $\mathrm{~cd}$ & 32.5 & $\mathrm{c}$ \\
\hline 11 & 77.5 & $\mathrm{a}$ & 7.5 & def & 0.1 & $\mathrm{f}$ & 12.5 & $\mathrm{a}$ & 2.5 & d \\
\hline 12 & 77.7 & $\mathrm{a}$ & 22.3 & cde & 1.5 & d & 0.0 & d & 0.0 & d \\
\hline control & 27.5 & cde & 72.5 & $\mathrm{a}$ & 5.4 & $\mathrm{a}$ & 0.0 & d & 0.0 & d \\
\hline
\end{tabular}

Means followed by the same letter in a column are not significantly different at $\mathrm{P} \geq 0.05$ (Duncan test).

Despite satisfactory results for several cultures in other works (Shackelford and Chlan, 1996), there are few reports of Augmentin ${ }^{\circledR}$ use in the Eucalyptus species, like for the hybrid $E$. grandis $x$ E. urophylla. Tournier et al. (2003) used the concentration of $300 \mathrm{mg} \mathrm{L}^{-1}$ of that antibiotic without damage to the culture and transformation of the species.

In the case of cefotaxime, the regeneration rates were lower than those obtained in the presence of Augmentin ${ }^{\circledR}$ in treatments 1 and 5, corresponding to $500 \mathrm{mg} \mathrm{L}^{-1}$ of this antibiotic for 15 and 30 days, respectively. The low percentages observed with these treatments could be attributed to different degrees of toxicity of that antibiotic for most of the plant tissues as mentioned by Pollock et al. (1983). Although cefotaxime had positive effects in cultures such as tobacco (Shackelford and Chlan,
1996), carbenicillin and timentin gave better results for the Eucalyptus species, possibly due to the hormonal effect that these penicillins could have on morphogenesis. Sarma et al. (1995) and Lin et al. (1995) indicated that cefotaxime acted as an auxin and therefore would induce the formation of calli and reduce explant regeneration capacity.For other species such as E. globulus, $E$. grandis, E. nitens, E. dunnii, E. pellita, E. robusta, $E$. saligna and the hybrid $E$. grandis $x E$. urophylla, cefotaxime has also been more frequently used with concentrations varying from 200 to $600 \mathrm{mg} \mathrm{L}^{-1}$, as well as carbenicillin, timentin and amoxicillin (Moralejo et al., 1998; Spokevicius et al., 2005; González, et al. 2001; Machado et al., 1997). However, these differences obtained for a same species are mainly linked to several factors that determine antibiotic efficiency 
in infection control, such as bacterial strain and plant tissue (Brasileiro and Dusi, 1999).

Another factor that might explain the differences in the result of the regeneration was the genetic variability of the plant material used, which was originated from the seeds obtained from a crossed pollination population and characteristic of the species (Allard, 1971). According to several authors, the genotypic variation presented by certain recalcitrant species in the Eucalyptus genus, could negatively influence the process of morphogenesis in vitro, mainly the protocols of genetic transformation (Lainé and David, 1994; Tibok et al., 1995; Barrueto Cid et al., 1999).

\section{CONCLUSIONS}

From the results obtained in this study, it could be concluded that:

- The amino type antibiotic Km was suitable for the selection of transformed cells at a concentration of $9 \mathrm{mg} \mathrm{L}^{-1}$;

- After the inoculation of E. camaldulensis explants with the $\mathrm{C} 58 \mathrm{C} 1$ strain, the bactericidal antibiotic should be maintained in the culture medium during the whole regeneration process until transgenic plants are produced;

- The maintenance of cefotaxime and Augmentin ${ }^{\circledR}$ in the culture medium, at the highest tested concentrations and for long periods, induced the necrosis and death of transformed explants;

- Augmentin ${ }^{\circledR}$ was efficient for the elimination of A. tumefaciens, allowing the regeneration from cotyledonary explants.

\section{RESUMO}

O presente trabalho teve como objetivos determinar o tipo e a concentração de antibióticos adequados para a eliminação de Agrobacterium tumefaciens de explantes inoculados e estabelecer a dose letal mínima do agente seletivo canamicina $(\mathrm{Km})$, sem interferir com o potencial regenerativo do explante cotiledonar de E. camaldulensis. Para a avaliação da eficiência dos antibióticos, cotilédones infectados com A. tumefaciens foram cultivados em meio MS N/2 com BAP, ANA, canamicina e cefotaxima ou Augmentina ${ }^{\circledR}$. Foi observada a maior média de brotos regenerados por explante $(5,4)$ na presença de $300 \mathrm{mg} . \mathrm{L}^{-1}$ de
Augmentina ${ }^{\circledR} / 15$ dias, seguido por $150 \mathrm{mg} \cdot \mathrm{L}^{-1} / 30$ dias, e $100 \mathrm{mg} . \mathrm{L}^{-1} / 30$ dias. Explantes cotiledonares não transformados foram cultivados em meio de cultura suplementado com antibiótico canamicina onde a concentração adequada para a seleção de células transformadas foi de $9 \mathrm{mg} \cdot \mathrm{L}^{-1}$.

\section{REFERENCES}

Allard, R. W. (1971), Princípios do melhoramento genético das plantas. São Paulo: Edgard Blücher, 381 p.

Angenon, G.; Dillen, W.; Van Montagu, M. (1994), Antibiotic resistance markers for plant transformation. In: Gelvin, S. B., Schilperoort, R. A. Plant molecular biology manual. Kluwer, Dordrecht, p. 1-13

Archilletti, T.; Lauri, P.; Damiano, C. (1995), Agrobacterium-mediated transformation of almond leaf pieces. Plant Cell Reports, 14, 267-272,

Barrueto Cid, L. P.; Machado, A. C. M. G.; Carvalheira, S. B. R. C.; Brasileiro, A. C. M. (1999), Plant regeneration from seedling explants of Eucalyptus grandis x E. urophylla. Plant Cell, Tissue and Organ Culture, 56, 17-23

Benveniste, R.; Davies, J. (1973), Mechanisms of antibiotic resistance in bacteria. Annual Review of Biochemistry, 42, 315-319

Brasileiro, A. C. M.; Dusi, D. M. A.(1999), Transformação genética de plantas. v.2, In: Torres, A. C.; Caldas, L.S.; Buso, J. A.. Cultura de tecidos e transformação genética de plantas. Brasília: EMBRAPA-SPI/EMBRAPA-CNPH,. p.679-735.

Brasileiro, A. C. M.; Aragão, F. J. L. (2001), Marker genes for in vitro selection of transgenic plants. Journal of Plant Biotechnology, 3 (3), 113-121

Brasileiro, A. C. M.; Lacorte, C. Interação Agrobacterium-hospedeiro. In: Brasileiro, A. C. M., Carneiro, V. T. C. (1998), Manual de transformação genética de plantas. Brasília, Brasil. EmbrapaSPI/Embrapa-Cenargen, p.75-92

Cervera, M., Pina, J. A., Juárez, J., Navarro, L., PENA, L. (1998), Agrobacterium-mediated transformation of citrange: factors affecting transformation and regeneration. Plant Cell Reports, 18, (3-4), 271-278,

Chen, Z.; Tsay, J.; Chung, J. (1996), Callus culture of Eucalyptus grandis $\mathrm{x}$ urophylla and preliminary studies on organogenesis and Agrobacteriummediated transformation. Taiwan Journal of Forest Sciences, 11 (1), 43-52

González, E. R. (2002), Transformação genética de Eucalyptus grandis e do híbrido E. grandis $\mathrm{x} E$. urophylla via Agrobacterium. Piracicaba, 93 f. Tese (Doutorado, Agronomia) - Escola Superior de Agricultura "Luiz de Queiroz", Universidade de São Paulo. 
González, E. R., Andrade, A. de, Bertolo, A. L., Lacerda, G. C., Carneiro, R. T., Defávari, V. A. P., Labate, C. A. (2000), The efficiency of aminoglycoside antibiotics in the regeneration and selection of Eucalyptus spp. Proceedings. In: International Conference Eucalyptus in the Mediterranean basin: perspectives and new utilization. Italy, p.45-48,

Harcourt, R. L.; Kyozuka, J.; Floyd, R. B.; Bateman, K. S.; Tanaka, H.; (2000), Decroocq, V.; Llewellyn, D. J.; Zhu, X.; Peacock, W. J.; Dennis, E. S. Insect and herbicide resistant transgenic eucalypts. Molecular Breeding, 6, 307-315

Ho, C. K.; Chang, S. H.; Tsay, J. Y.; Tsai, C. J.; Chiang, V. L.; Chen, Z. Z. (1998),

.Agrobacterium tumefaciens-mediated Transformation of Eucalyptus camaldulensis and production of transgenic plants. Plant Cell Reports, 17, 675-680

Kawazu, T.; Dol, K.; Tatemichi, Y.; Ito, K.; Shibata, M. (1996), Regeneration of transgenic plants by nodule culture systems in Eucalyptus camaldulensis. In: CONFERENCE OF TREE IMPROVEMENT FOR SUSTAINABLE TROPICAL FORESTRY, 1996, Caloundra. Proceedings. Caloundra: IUFRO, p.492497.

Lainé, E.; David, A. (1994), Regeneration of plants form leaf explants of micropropagated Eucalyptus grandis. Plant Cell Reports, 13, 473-476

Laplaze, L.; Gherbi, H.; Duhoux, E;, Powlowski, K.; Auguy, F.; Guermanche, F.; Franche, C.; Bogusz, D. (2002), Symbiotic and non-symbiotic expression of cgMT1, a metallothionein-like gene from the actinorhizal tree Casuarina glauca. Plant Molecular Biology, 49, 81-92

Lin, J-J, Assad-Garcia, N., Kuo, J. (1995), Plant hormone effect of antibiotics on the transformation efficiency of plant tissues by Agrobacterium tumefaciens cells. Plant Science, 109, 171-177

Machado, L. O. R.; Andrade, G. M., Cid, L. P. B., Penchel, R. M. (1997), Agrobacterium strain specificity and shooty tumour formation in eucalypt (Eucalyptus grandis $\times$ Eucalyptus urophylla). Plant Cell Reports, 16, 299-303

Mayolo, G. A. de; Maximova, S. N.; Pishak, S.; Guiltinan, M. J. (2003)Moxalactam as a counterselection antibiotic for Agrobacterium mediated transformation and its positive effects on Theobroma cacao somatic embryogenesis. Plant Science, 164, 607-615

Moralejo, M., Rochange, F., Boudet, A. M., Teuliéres, C. (1998), Generation of transgenic Eucalyptus globulus plantlets through Agrobacterium tumefaciens mediated transformation. Australian Journal of Plant Physiology, 25 (2), p.207 - 212

Mullins, K. V., Llewellyn, D. J., Hartney, V. J., Strauss, S., Dennis, E. S. (1997), Regeneration and transformation of Eucalytus camaldulensis. Plant Cell Reports, 787-791
Murashige, T.; Skoog, F. (1962), A revised medium for rapid growth and bio-assays with tobacco tissue cultures. Physiologia Plantarum, 15, 473-497

Nauerby, B.; Billing, K.; Wyndaele, R. (1997), Influence of the antibiotic timentin on plant regeneration compared to carbenicillin and cefotaxime in concentrations suitable for elimination of Agrobacterium tumefaciens. Plant Science, 123, p.169-177

Picoli, E. A. DE T.; Cecon, P. R.; Fári, M. G.; Otoni, W. C. (2002), Organogenesis in eggplant (Solanum melongena L. cv. Embú) as affected by antibiotics and growth regulators. International Journal of Horticultural Science, 8 (2), 76-82

Pollock, K.; Barfield, D. G.; Shields, R. (1983), The toxicity of. antibiotics to plant cell cultures. Plant Cell Reports, 2, 36-39,

Potrykus, I.; Spangenber, G. G. (1995), Gene transfer to plant. Springer: Laboratory Manual, 328p.

Sarma, K. S.; Evans, N. E.; Selby, C. (1995), Effect of carbenicillin and cefotaxime on somatic embryogenesis of sitka spruce (Picea sitchensis (Bong.) Carr.). Journal of Experimental Botany, 46, (292), 1779-1781

Shackelford, N. J.; Chlan, C. A. (1996), Identification of antibiotics that are effective in eliminating Agrobacterium tumefaciens. Plant Molecular Biology Reporter, 14, 50-57

Spokevicius, A. V.; Van Beveren, K.; Leitch, M. A.;.Bossinger, G. (2005), Agrobacterium-mediated in vitro transformation of wood-producing stem segments in eucalypts. Plant Cell Reports, 23 (9), 617-624

Sullivan, J.; Lagrimini, L. M. (1993), Transformation of Liquidambar styraciflua using Agrobacterium tumefaciens. Plant Cell Reports,12, (6), 303-306

Tibok, A.; Blackhall, N. W.; Power, J. B.; Davey, M. R. (1995), Optimized plant regeneration from callus derived from seedling hypocotyls of Eucalyptus urophylla. Plant Science, 110, 139-145

Tournier, V.; Grat, S.; Marque, C.; El Kayal, W.; Penchel, R.; Andrade, G. de; Boudet, A.; Teulières, C. (2003), An efficient procedure to stably introduce genes into an economically important pulp tree (Eucalyptus grandis $\times$ Eucalyptus urophylla). Transgenic Research, 12, 403-411

Tsai, C. J.; Podila, G. K.; Chiang, V. L. (1994), Agrobacterium-mediated transformation of quaking aspen (Populus tremuloides) and regeneration of transgenic plants. Plant Cell Reports, 14, 94-97

Yepes, L. M.; Aldwinckle, H. S. (1994), Factors that affect leaf regeneration efficiency in apple, and effect of antibiotics in morphogenesis. Plant Cell, Tissue and Organ Culture, 37 (3), 257-269.

Received: March 23, 2007; Revised: August 17, 2007; Accepted: December 23, 2008. 